\title{
MADRASAH DAN PERTUMBUHAN KEILMUAN DUNIA ISLAM: SEBUAH KAJIAN SOSIO-HISTORIS
}

\author{
Imam Solihin \\ Pascasarjana Institut Agama Islam Negeri Metro \\ Jl. Ki Hajar Dewantara 15A Iring Mulyo Kota Metro \\ Email: solihin.m2m@gmail.com
}

\begin{abstract}
This article was aimed at deeply discussing the development of madrasah and sciences in Islamic society from the socio-historical perspective. In the past, Islamic education was only implemented informally at homes, kuttab and mosque. In further development, after the Muslim community began to form, education was organized in a formal form, so that Islamic education later became one of the pillars of Islamic civilization. In this case, formal form of Islamic education is characterized by the emergence of madrasah as an educational institution and as well as an educational path. Inside the madrasah there is a pedagogical process of communication between educators of learners, from which it is expected to lead to the achievement of instructional goals. It can be said that historically the birth of a madrasah became a symbol of the awakening of the Islamic educational system. In the history of madrasah development in Indonesia, there are two types of madrasah, madrasah diniyah and non-diniyah madrasah. Madrasah diniyah is a religious education institution whose curriculum is $100 \%$ religious material. The nondiniyah madrasah is a religious education institution whose curriculum, in addition to religious material, covers a general subject with a diverse percentage.
\end{abstract}

Keyword: madrasah, development,Islamic education, Islamic sciences

\begin{abstract}
Abstrak
Artikel ini membahas secara mendalam perkembangan madrasah dan perkembangan keilmuan di kalangan masyarakat Islam dilihat dari perspektif sosio-historis. Awalnya, pendidikan Islam dilaksanakan secara informal di rumah-rumah, kuttab dan masjid. Pada perkembangan selanjutnya, setelah masyarakat Muslim mulai terbentuk, pendidikan diselenggarakan dalam bentuk formal, sehingga pendidikan Islam kemudian menjadi salah satu pilar dari peradaban Islam. Dalam hal ini, pendidikan Islam bentuk formal ditandai oleh munculnya madrasah sebagai lembaga pendidikan dan sekaligus sebagai jalur pendidikan. Di dalam madrasah berlangsung proses komunikasi pedagogis antara pendidik peserta didik, yang darinya diharapkan mengarah kepada tercapainya tujuan instruksional. Dapat dikatakan bahwa secara historis kelahiran madrasah menjadi lambang kebangkitan dari sistem pendidikan Islam. Sedangkan perkambangan Madrasah di Indonesia Dalam sejarah perkembangan madrasah di Indonesia, dikenal dua jenis madrasah, madrasah diniyah dan madrasah non-diniyah. Madrasah diniyah merupakan lembaga pendidikan keagamaan yang kurikulumnya 100\% materi agama. Adapun madrasah non-diniyah adalah lembaga pendidikan keagamaan yang kurikulumnya, di samping materi agama, meliputi mata pelajaran umum dengan prosentase beragam.
\end{abstract}

Kata Kunci: Madrasah, Perkembangan, Pendidikan Islam, ilmu-ilmu Islam 


\section{Pendahuluan}

Perkembangan dalam menuntut ilmu pada zaman sekarang lebih modern dibandingkan dengan keadaan pada zaman dahulu. Bahkan proses belajar mengajarnya sangat berbeda sekali. Pada zaman sekarang, dimanapun kita

bisa belajar karena adanya kemajuan teknologi, sedang padazaman sahabat proses belajarnya harus dilakukan dengan cara berpindahpindah dari rumah-kerumah sahabat; salah satu yang paling terkenal adalah Darul Al-Arqom. Menurut Maksum, setelah masyarakat Islam telah terbentuk, proses penyampaian ilmu dan belajar mengajar dilakukan di masjid atau yang lebih dikenal dengan istilah halaqoh. ${ }^{1}$

Perkembangan ilmu-ilmu Islam dapat kita lihat dalam berbagai priode; dari daulah Abasiyah, daulah Fatimiyah, daulah Usmaniyah, dalam abad ke-4 $\mathrm{H}$ atau $10 \mathrm{M}$. Pengaruhnya sampai pada abadabad kemudian tampak jeles terhadap perkembangan peradaban di negaranegara barat seperti Spanyol, Perancis dan sebagainya. Di samping itu, perjuangan muslim dalam berbagai ilmu pengetahuan seperti filsafah, kimia, astronomi, aljabar, kedokteran, dan arsitektur dalam sejarah peradaban Islam pada abad tersebut pun sangat signifikan.

Bagi para pelajar muslim hari ini, sangat perlu untuk mengetahui bagaimana sejarah perkembangan madrasah dan keilmuan di kalangan masyarakat Islam di masa lampau. Hal ini dimaksudkan para generasi muslim muda dapat terinspirasi dan kemudian menjadi lebih optimis untuk menjadi pelajar yang berkualitas dan mampu berkompetisi dengan para pelajar yang lain.

1 . Tuti Sulastri, "Fungsi Madrasah dalam Pengembangan Ilmu Pengetahuan Islam" 11 Desember 2016 Vol. 3 No. 2, no. Jurnal Qathrunâ (14 September 2017): 127.

\section{Landasan Teori}

\section{Pertumbuhan Ilmu Islam}

Pendidikan Islam tidak akan pernah ada habisnya. Demikian, karena proses pendidikan Islam telah, sedang dan akan terus berjalan mengikuti perkembangan zaman. Dalam pengertian yang seluasluasnya, pendidikan Islam berkembang seiring dengan kemunculan Islam itu sendiri. Dalam sejarah masyarakat Arab, di mana Islam lahir dan pertama kali berkembang, kedatangan Islam lengkap dengan usahausaha pendidikan merupakan transformasi besar. Sebab pada dasarnya masyarakat Arab pra Islam tidak mempunyai sistem pendidikan formal. Pendidikan yang berlangsung dapat dikatakan lebih bersifat informal, dan ini pun lebih berkaitan dengan upaya dakwah Islamiyah, penyebaran dan penanaman dasar kepercayaan dan ibadah lain.

Ketika menjelaskan sejarah pertumbuhandanperkembanganpendidikan Islam di Indonesia, Mahmud Yunusmenyebut tahun 1900 M sebagai era pembatas antara masa sebelum dan sesudahnya. ${ }^{2}$ Sebelum tahun $1900 \mathrm{M}$, pendidikan Islam berlangsung secara tradisional dalam bentuk pendidikan surau/langgar dan pesantren. Materi pelajaran murni diniyah; metode mengajar bersifat individual, ceramah, dan hafalan; belum menggunakan meja-kursi, papan tulis, dan dengan munculnya lembagalembaga pendidikan Islam modern berupa madrasah dan sekolah umum berciri khas Islam. Secara umum, kemunculan lembagalembaga modern ini ditandai dengan perubahan pada aspek-aspek; kurikulum (memperkenalkan mata pelajaran umum), metode (memperkenalkan metode-metode mengajar modern), dan sarana (mulai menggunakan meja, kursi, papan tulis, dan sistem kelas).

2 Mahmud Yunus, Sejarah Pendidikan Islam di ndonesia (jakarta: hidakarya agung, n.d.). 
Karena itu, tak heran ketika Charles Michael Stanton tidak berhasil membuktikan kaitan yang jelas antara lembaga pendidikan tinggi Islam dengan kemajuan berbagai cabang sains dalam peradaban Islam. Ini tidak aneh karena seluruh madrasah yang pernah diteliti sepenuhnya bermuatan ilmu-ilmu agama. Hanya terdapat beberapa madrasah saja, khsususnya di Persia yang mengajarkan beberapa bidang ilmu yang "diharamkan" pada madrasah-madrasah Sunni.

\section{Sejarah Pertumbuhan dan Perkembangan Madrasah}

Kata madrasah dalam bahasa Arab "madrasatun" berarti tempat atau wahana untuk mengenyam proses pembelajaran. Dalam bahasa Indonesia, madrasah disebut dengan sekolah yang berarti bangunan atau lembaga untuk belajar dan memberi pengajaran. Karenanya, istilah madrasah tidak hanya diartikan sekolah dalam arti sempit, tetapi juga bisa dimaknai rumah, istana, kuttab, perpustakaan, surau, masjid, dan lain-lain, bahkan seorang ibu juga bisa dikatakan madrasah pemula. Dari pengertian di atas maka jelaslah bahwa madrasah adalah wadah atau tempat belajar ilmu-imu keIslaman dan ilmu pengetahuan keahlian lainnya yang berkembang pada zamannya.

Dengan demikian dapat disimpulkan bahwa istilah madrasah bersumber dari Islam itu sendiri. Dalam perkembangannya di Indonesia, madrasah Islamiyah ini merupakan lembaga yang berdiri jauh sebelum SD, SMP, SMU/ SMK, atau perguruan tinggi/ Universitas. Sebab madrasah adalah salah satu sarana atau media tempat yang strategis bagi kyai/ ustadz dengan masyarakat dalam rangka menyampaikan aspek-aspek ajaran Islam. Melalui madrasah juga, para raja muslim, menyampaikan program kenegaraan dan keagaman yang dianutnya. ${ }^{3}$

3 KM. Akhiruddin, "Lembaga Pendidikan Islam di Nusantara," 25 Juni 2015 Vol 1, no. No 01 (14 September 2017): 204.

\section{Institusi Pendidikan Islam}

Institusi sosial yang paling dekat hubungannya dengan ulama adalah institusi pendidikan yang berhubungan dengan statusnya sebagai elite intelektual. Hubungan ulama dan institusi pendidikan hadir dalam bentuk suatu hubungan yang mutual saling terkait dan saling membutuhkan. Ada dua pola hubungan ulama dan institusi pendidikan Islam. Di satu sisi lembaga pendidikan Islam adalah merupakan sarana transmisi keilmuan bagi ilmu yang dimiliki oleh ulama, sementara di sisi lain, institusiinstitusi formal atau tidak formal dari pendidikan adalah sarana pembentukan dan pengkaderan ulama. Salah satu sistem yang memungkinkan peroses kependidikan Islam berlangsung secara konsisten dan berkesinambungan dalam angka mencapai tujuannya adalah intitusi atau lembaga pendidikan Islam. Dalam sejarah pendidikan Islam sejak nabi melaksanakan tugas agama secara aktif, di kota Mekkah telah didirikan lembaga dimana Nabi memberikan pelajaran tentang agama Islam secara menyeluruh di rumah rumah dan di masjid-masjid. Salah satu rumah yang terkenal dijadikan tempat berlangsungya pendidikan Islam ialah Dar alArqam di mekkah dan masjid yang terkenal dipergunakan untuk kegiatan belajar dan mengajar ialah yang sekarang terkenal Masjid al-Haram dan masjid Annabawy di Madinah al-Munawwarah. Di dalam masjid inilah berlangsung peroses belajar mengajar berkelompok dalam halaqah dengan masing masing gurunya yang terdiri dari para sahabat Nabi.

Sejalan dengansemakin meningkatnya jumlah pemeluk Islam dan juga keinginan untuk memperoleh efektifitas belajar mengajar yang cukup memadai, berpikirlah para sahabat dan tabiin tetang pendidikan yang berkelanjutan sampai munculnya kerajaan Islam di Timur Tengah dan Spanyol. Mereka mendirikan berbagai model kelembagaan pendidikan Islam yang 
lebih teratur dan terarah dalam kegiatan belajar dan mengajar secara klasikal yang berbentuk madrasah. Mula mula berdiri lembaga pendidikan yang bernama kuttab salah satu lembaga pendidikan dasar yang di dalamnya di ajarkan cara membaca dan menulis huruf Al Qu'an serta pengajaran ilmu agama serta ilmu al Qur'an.

Orang yang pertama kali belajar menulis dari penduduk Mekkah adalah Sufyan bin Umayah dan Abu Qais bin Abdul Manaf Bin Sahrah Bin Kilab, sedangkan pengajarnya ialah Basyar Bin Abdul Malik yang pernah belajar menulis di Irak. Dari mereka inilah kegiatan belajar menulis dan membaca Al-Quran menyebar ke seluruh penjuru jazirah. Arab. Motivasi utama dari kegiatan belajar menulis dan membaca AlQuran bersumberkan dari wahyu pertama yang diturunkan kepada Rasulullah yang tersebut dalam Surah Al 'Alaq.

Dari kemampuan menulis dan membaca inilah umat Islam memperoleh sarana yang ampuh untuk belajar ilmuilmu yang lain. Oleh karena itu, membaca dan menulis dapat di pandang sebagai sumbernya ilmu pengetahauan manusia yang semakin berkembang.

Pendidikan Islam merupakan sebuah trans-internalisasi ilmu pengetahuan dan nilai-nilai keIslaman melalui upaya pembelajaran, pembiasaan pengawasan dan pengembangan potensi peserta didik untuk kehidupan yang baik di dunia dan akhirat. ${ }^{4}$ Ilmu pengetahuan dalam konsep Islam juga harus selaras dengan karakter peradaban Islam. Ilmu Pengetahuan harus berwatak humanis-religius, yang setidaknya didasarkan pada beberapa prinsip berikut: ${ }^{5}$

4 Abdul Mujib dan Ahmad Madkur, Islamicbased Life Skill Education on State Vocational High Schools in Metro. Makalah disampaikan di The First International Conference on Law, Economics and Education. (Metro: Universitas Muhammadiyah Metro, 2016), 43-47.

5 Umar Sulaiman, Islam Kosmopolitan: Ikhtiar Pembumian Nilai-Nilai Transenden-Humanis di Ruang Publik (Yogyakarta: Freshbooks, 2012), 325-31.
Pertama, ilmu pengetahuan dalam Islam dikembangkan dalam kerangkan tauhid atau teologi. Yaitu teologi yang bukan semata-mata meyakini adanya Allah SWT. dalam hati, mengucapkan dengan lisan dan mengamalkan dengan tingkah laku, melainkan teologi yang menyangkut aktivitas mental berupa kesadaran manusia yang paling dalam perihal hubungan manusia dengan Allah SWT., lingkungan dan sesama. Lebih tegasnya adalah teologi yang memunculkan kesadaran, yakni suatu mantra yang paling dalam diri manusia yang merubah pandangan dunianya dan kemudian menghasilkan pola sikap dan tindakan yang selaras dengan pandangan dunia itu. Oleh karena itu, teologi pada ujungnya akan mempunyai implikasi yang sangat sosiologis, sekaligus antropologis. ${ }^{6}$

Sejarah mencatat bahwa terdapat begitu banyak ilmuwan muslim yang memiliki pengaruh besar di berbagai bidang ilmu pengetahuan seperti falsafah, kimia, astronomi, aljabar, kedokteran, dan arsitektur dalam sejarah kebudayaan Islam pada abad ke-4 $\mathrm{H}$ atau $10 \mathrm{M}$.

Bahkan seorang ilmuwan sejarah berkebangsaan Inggris, Philip K. Hitti dalam tulisannya menunjukan fakta tentang kemajuan umat Islam pada abad pertengahan dengan menyatakan "Yang tercipta oleh bangsa Arab bukan hanya suatu kerajaan, melainkan juga suatu kebudayaan. Mereka adalah ahli waris dari kebudayaan lama yang berkembang di tepi sungai Tigris dan Eurat serta di lembah sungai Nil dan pesisir timur laut tengah. Kemudian sifat sifat utama dari kebudayaan Yunani-Romawi juga di pelajari dan di kembangkan. Oleh karena itu, mereka yang memberikan bayak pengaruh kebudayaan ini ke Benua eropa pada abad pertengahan, sehingga Eropa terbangun dari tidurya dan berkembanglah

6 Syamsul Arifin, et, al, Spiritualitas Islam dan Peradaban Masa Depan (Yogyakarta: SIPPRESS, 1996), 21. 
renaissance modern.

Dalam permulaan abad pertengahan itu, tidak ada suatu bangsa pun yang besar subangannya bagi proses kemajuan manusia kecuali bangsa Arab yang saat ini sudah asyik mempelajari falasafah Arisoteles sementara Kare Agung (kaisar nama 1 Perancis saat itu) berserta pembesar pembesarnya masih asik belajar menuliskan namanya.

Kemajuan peradaban umat Islam pada masa itu merupakan hasil dari kemampuan membaca dan menulis yang pertama-tama di perintahkan oleh oleh Allah melalui wahyu kepada utusan-Nya Muhammad SAW. Kegiatan belajar mengajar yang diawali dengan membaca dan menulis itu, akhirnya mendorong umat Islam untuk belajar dalam bidang-bidang ilmu pengetahuan di luarilmu agama, di samping karena kebutuhan hidup yang semakin berkembang, terutama tentang ilmu alam, serta kemasyarakatan, dan falsafah.

Oleh karena itu, sistem kuttab tidak mampu menampung aspirasi dari kebutuhan belajar yang lebih luas dan dalam maka bentuklah system pendidikan klasikal yang di kenal dengan madrasah atau sekolah. Madrasah yang pertama ialah Madrasah an Nidhamiyah yang di dirikan oleh Nidham al-Mulki seorang Menteri Sultan Malik Syah as Seljuqy pada tahun 460-475 H di kota Baghdad dan Naesabur dengan mengunakan namaya. Imam al Gozalai pernah menjadi guru madrasah tersebut di Baghdad kemudian di Naesabur, pada akhir abad ke-5 M.

Kemudian disusul berdirinya madrasah-madrasahlainyasepertiMadrasah an-Nasiriyah, Madrasah alQumhiyah dan as-Saefi'yah dari daulah Ayyubijah. Pada akhirnya bermunjulan berbagai jenis madrasah tersebut di timur tengah seperti di Syiria, terkenal madrasah an-Nuriyah yang didirikan oleh nuruddin Zangky. Di Mesir dengan mandrasah al- Kamaliyah (didirikan oleh malik al -kamil al-Ayyub). Madrasah al Dhahiriyah di mana fikih mazhab as-Syafi'y dan Hanafy di ajarkan.

Madrasah

al-Manshuriyah

merupakan madrasah yang mengajarkan fikih dari keempat mazhab, hadits, serta ilmu kedokteran. Masdrasah an Nashiriyah mengajarkan keempat mazhab fikih begitu juga madrasah sultan hasan yang yang didirikan pada tahun $758 \mathrm{M}$ terkenal karena besarnya bangunan, arsitektur nya yang indah serta bentuknya yang hebat yang tak ada tandinganya di seluruh dunia Islam. Madrasahini didirikan pada zaman Kerajaan Malik di Mesir.

Pada setiap madrasah yang di dirikan itu selalu di lengkapai dengan pepustakaan dengan beribu ribu jilid buku di dalamnya. Sistem madrasah (klasikal), pendidikan Islam berkembang pula dalam institusi kependidikan yang disebut Zawiyah yaitu suatu tempatbelajar disudut masjid (menurut asal usulnya). Kemudian pengertian zawiyah ini mejadi meluas sehingga akhirnya di kenal sebagai "tempat belajar yang terpisah dari bangunan masjid "yang hampir menyamai fungsi madrasah, oleh karena zawiyah ini tidak lagi di gunakan untuk melakukan itikaf atau taabbud terutama bagi kaum sufi atau tarikat,dan akhirnya menjadi tempat mengajarkan al-Qur'an dan agama serta dasar-dasar ilmu pengetahuan umum. Fungsi Zawiyah hampir sama dengan fungsi madrasah, lembaga ini berkembang pada abad ke-8 H di Negara Negara Maghribi (Afrika Utara).

Institusi kependidikan Islam berkembangdalambentukformal(madrasah) semua jenjang sampai dengan Universitas (al-Jamiyah) dan bentuk nonformal (masjelis taklim, pesantren) dan pendidikan individual (langsung dengan guru, ulama).

Pada masa-masa paling awal, pendidikan Islam bersifat sangat sederhana dan baru dilaksanakan secara informal 
di rumah-rumah, kuttab dan masjid. Pada perkembangan selanjutnya, setelah masyarakat Muslim mulai terbentuk, pendidikan diselenggarakan dalam bentuk formal, sehingga pendidikan Islam kemudian menjadi salah satu pilar dari peradaban Islam. Dalam hal ini, pendidikan Islam bentuk formal ditandai oleh munculnya madrasah sebagai lembaga pendidikan dan sekaligus sebagai jalur pendidikan. Di dalam madrasah berlangsung proses komunikasi pedagogis antara pendidik-peserta didik, yang darinya diharapkan mengarah kepada tercapainya tujuan instruksional. Dapat dikatakan bahwa secara historis kelahiran madrasah menjadi lambang kebangkitan dari sistem pendidikan Islam.

Dengan menggunakan pendekatan sosio-historis, di dalam tulisan ini akan ditelusuri kelahiran madrasah dalam perkembangan pendidikan Islam. Objek kajian ini utamanya terfokus pada madrasah Nizamiyyah di Baghdad. Pasalnya, madrasah tersebut adalah salah satu di antara madrasah-madrasah yang diperdebatkan oleh pemerhati sejarah pendidikan Islam.

\section{Madrasah}

Madrasah adalah satu jenis yang lain dari lembaga pendidikan tinggi, dan ia mulai muncul pada akhir abad ke IV Hijriyah. Berkembangnya madrasah-madrasah dalam waktu yang cepat itu merupakan satu manifestasi yang bertujuan untuk melawan golongan Syi'ah yang telah kuat dan berkembang di seluruh pelosok dunia Islam pada abad ke IV Hijriyah. Gerakan Syi'ah ini bukan saja merupakan gerakan politik yang dikembangkan oleh pengikut-pengikut Ali untuk mengendalikan pemerintahan, akan tetapi dalam waktu yang sama ia juga merupakan satu gerakan ilmu pengetahuan yang sejalan dengan falsafah pendapatpendapat golongan mistik yang beraliran extrem. Gerakan ini telah mendapat tentantan yang hebat dari penganut mazhab ahlus-
Sunnah. Munculnya orang-orang pada abad ke XI Masehi yang merupakan golongan pendukung mazhab ahlus-sunnah yang fanatik terhadap kepercayaan agama, dan jatuhnya sebagian besar dari kerajaan Islam dalam tangan mereka, dan sikap mereka yang sangat setia kepada khilafah, Kesemuanya ini merupakan faktor-faktor yang utama yang dapat mengukuhkan mazhab ahlussunnah dan melemahkan pengaruh dan kedudukan golongan Syi'ah. Munculnya madrasahmadrasah yang banyak dalam abad ini telah menjadi satu alat untuk menyatakan satu sikap baru dalam berpikir dan untuk melahirkan gelora semangat keagamaan yang meluap-luap pada masa ini, sehingga terjadi perang salib di antara umat Islam dan Kristen. Madrasah-madrasah tersebut tersebar hampir di seluruh dunia Islam untuk memperkuat mazhab ahlussunnah dengan cara memberi perhatian yang besar terhadap mempelajari ilmu fiqh yang terdapat di dalam empat mazhab.

AdapundiMesir, madrasah-madrasah baru didirikan sesudah hilangnya kerajaan Fatimiyah dan sesudah berdirinya kerajaan Ayyubiyah. Pada masa kerajaan Ayyubiyah inilah didirikan madrasah-madrasah sehingga tersebar sangat luas. Penebaran madrasah-madrasah ini tetap berjalan terus pada masa Al-Mamalik, demikian pula di Syria madrasah-madrasah banyak didirikan pada masa ini.

Biasanya sebuah madrasah dibangun untuk salah seorang ahli figh yang termasyhur dalam satu mazhab yang empat. Umpamanya Nuruddin Mahmud bin Zanki telah mendirikan di Damaskus dan Halab beberapa Madrasah untuk mazhab Hanafi dan Syafi'i, dan telah dibangun pula sebuah madrasah untuk kedua mazhab ini di kota Mesir.

Madrasah itu tidak berbeda dari Mesjid atau Jami', baik dari segi bangunan, tugas, maupun tujuannya. Hanya madrasah 
itu lebih lengkap persiapannya untuk studi dan untuk tempat tinggal bagi pelajar-pelajar yang belajar secara fulltime. Madrasahpun telah digunakan pula untuk melaksanakan tujuan-tujuan masjid, seperti digunakan untuk melakukan shalat sebagaimana dilakukan di masjid-masjid, kemudian madrasah itu juga diguna-kan sebagai pengadilan. Namun demikian madrasah itu mempunyai tugas pokok yang tersendiri, yaitu untuk mengajar fiqh yang sejalan dengan satu atau lebih dari mazhab ahlussunnah yang empat itu, dengan cara menarik para pelajar-pelajar untuk menggunakan waktu mereka sepenuhnya dalam belajar, dan memberikan gaji tetap bagi para guru, sehingga mereka tidak usah mencari pekerjaan lain untuk mencari penghidupan mereka.

Walaupun tadi telah dikatakan bahwa tugas pokokbagi madrasah-madrasah adalah untuk mengajar ilmu fiqh semata-mata, akan tetapi ada juga sebagian madrasah yang memberi pelajaran kedokteran di samping ilmu fiqh.

Madrasahsebagailembagapendidikan dalam bentuk pendidikan formal sudah dikenal sejak awal abad ke- 11 atau $12 \mathrm{M}$, atau abad ke- 5-6 H, yaitu sejak dikenal adanya Madrasah Nidzamiyah yang didirikan di Baghdad oleh Nizam Al-Mulk, seorang wazir dari Dinasti Saljuk. Pendirian Madrasah ini telah memperkaya khasanah lembaga pendidikan di lingkungan masyarakat Islam, karena pada masa sebelumnya masyarakat Islam hanya mengenal pendidikan trdisional yang di selenggarakan di masjid-masjid dan Dar al-Khuttab. Di Timur Tengah institusi madrasah berkembang untuk menyelenggarakan pendidikan keIslaman tingkat lanjut (advance/tinggi), yaitu melayani mereka yang masih haus ilmu sesudah sekian lama menimbanya dengan belajar di masjid-masjid. Dengan demikian, pertumbuhan madrasah sepenuhnya merupakan perkembangan lanjut dan alamiah dari dinamika internal yang tumbuh dari dalam masyarakat Islam itu sendiri.

Di Indonesia, keadaannya tidak demikian. Madrasah merupakan fenomena moderen yang muncul pada awal abad ke20. Berbeda dengan di Timur Tengah di mana madrasah adalah lembaga pendidikan yang memberikan pelajaran ilmu agama tingkat lanjut, sebutan madrasah di Indonesia mengacu kepada lembaga pendidikan yang memberikan pelajaran agama Islam tingkat rendah dan menengah. Perkembangannya diperkirakan merupakan reaksi terhadap faktor-faktor yang berkembang dari luar lembaga pendidikan yang secara tradisional sudah ada, terutama munculnya pendidikan modern Barat. Dengan kata lain, tumbuhnya madrasah di Indonesia adalah hasil tarik menarik antara pesantren sebagai lembaga pendidikan asli (tradisional) yang sudah ada di satu sisi, dengan pendidikan Barat (modern) di sisi lain.

Apabila ditelusuri masuknya agama Islam di Indonesia, maka agama Islam datang ke Indonesia dibawa oleh pedagangpedagang dari Gujarat, disiarkan secara damai tanpa paksaan, dalam penyiaran Islam pada tahun-tahun pemulaan dilakukan oleh pemuka masyarakat yang dikenal dengan sebutan para wali. Para wali inilah yang berjasa mengembangkan agama Islam, terutama di Pulau Jawa, yang dikenal dengan sebutan Wali Songo.

Para wali menyiarkan agama Islam dengan cara bijaksana, kebiasaan yang hidup dan berkembang di kalangan masyarakat sepenuhnya tidak dihilangkan, bahkan adat istiadat dan kebiasaan dilindungi dan dikembangkan, disesuaikan dan diisi dengan ajaran agama Islam. Karena itu maka tidak heran apabila sampai sekarang kita masih melihat adanya adat istiadat nenek moyang yang masih melekat pada umat Islam. Orang-orang yang kemudian masuk Islam ingin mempelajari dan mengetahui 
lebih lanjut tentang ajaran Islam, orang ingin bisa mengerjakan shalat, bisa membaca Al Qur'an dan berdo'a. Dari sinilah mulai tumbuh pendidikan agama Islam, pada mulanya mereka belajar dari rumah-rumah, di Langgar, di Masjid, dan kemudian berkembang menjadi Pondok Pesantren.

Dalam perkembangan selanjutnya lembaga pesantren ini mendapatkan perhatian para sultan, sesuai dengan kedudukan tinggi para wali di mata sultan, tidak sedikit pesantren yang mendapatkan perhatian dan bantuan dari sultan. Contohnya nama Tegalsari yang merupakan hadiah dari sultan kepada kyai atas jasajasanya. Pondok Pesantren Tegalsari sampai aad ke-19 merupakan Pndok terkemuka di Jawa, bahkan santrinya banyak yang berasal dari Sumatra, Kalimantan, dan dari luar Pulau lainnya.

\section{Pertumbuhan dan Perkembangan Madrasah}

a. Dilema Kelembagaan dan Pendidikan Madrasah

Salah satu hal yang penting dan perlu disimak dalam sejarah perkembangan penyelenggaraan sekolah-sekolah agama ialah lahirnya Keppres No. 34 tahun 1974 tantang tanggungjawab fungsional pendidikan dan latihan serta Inpres No. 15 tahun 1974 tentang pelaksanaan Keppres.

Dalam realitas pendidikan Islam di tanah air, saat dibicarakan tentanglembaga pendidikan Islam, selain pesantren, maka yang segera terbayang di benak kita adalah madrasah. Institusi pendidikan ini lahir pada awal abad XXM., yang dapat dianggap sebagai periode pertumbuhan madrasah dalam sejarah pendidikan Islam di Indonesia. Memasuki abad XXM., banyak orang Islam Indonesia mulai menyadari bahwa mereka tidak akan mungkin berkompetisi dengan kekuatan-kekuatan yang menantang dari pihak kolonialisme Belanda, penetrasi Kristen, dan perjuangan untuk maju di bagian-bagian lain di Asia, apabila mereka terus melanjutkan kegiatan dengan cara-cara tradisionaldalam menggerakan Islam

Munculnya kesadaran "kritis" di kalangan umat Islam Indonesia tidak bisa dilepaskan dari kiprah kaum terdidik lulusan pendidikan Mesir atau Timur Tengah yang telah banyak menyerap semangat pembaruan (modernisme) di sana. Sekembalinya ke tanah air, mereka melakukan pengembangan institusi pendidikan baru yang lazim disebut madrasah dengan menerapkan metode dan kurikulum yang juga baru. Dari sini, tidak mengherankan bila kemudian terjadi beberapa perubahan mendasar dalam dinamika Islam Indonesia yang setidaknya didorong oleh empat faktor penting, yaitu:

1. Diberbagai tempat di dunia Islam muncul kecenderungan kuat untuk kembalikeAlQur'an dan Hadist nabi yang dijadikan titik tolak menilai kebiasaan agama dan kebudayaan yang ada.

2. Gejolak dan sifat perlawanan nasional terhadap penguasa kolonial Belanda.

3. Usaha yang kuat dari umat Islam untuk memperkokoh organisasinya di bidang sosialekonomi, demikepentingan mereka sendiri maupun untuk kepentingan rakyat banyak.

4. itu, apabila dilihat dari sudut pandang pendidikan modern Barat kolonial, kehadiran madrasah mengandung dimensi "akulturatif" karena ia merupakan manifestasi dan realisasi pembaruan sistem pendidikan Islam yang diinginkan oleh sebagian umat Islam yang tengah menganggap. Pemburuan pendidikan Islam yang disebabkan karena munculnya ketidakpuasan terhadap pola tradisional.

5. pembaharuan Islam yang telah ada. Berdirinya madrasah adalah bagian dari kesadaran umat Islam Indonesia untuk membangun kekuatan melawan kolonialisme Belanda, penetrasi Kristen 
serta keinginan untuk maju sejajar dengan bangsa-bangsa lain di Asia.

\section{Madrasah pada Awal Masa Kemerdekaan}

Di awal kemerdekaan, tidak dengan sendirinya Madrasah dimasukan kedalam sistem pendidikan nasional. Madrasah memang terushidup tetapitidakmemperoleh bantuan sepenuhnya dari pemerintah. madrasah dan dunia pendidikan Islam pada umumnya dibiarkan hidup meskipun dalam keadaan yang sangat sederhana dan hidup apa adanya. Perhatian peerintah pada saat itu hanyalah sebatas dorongan moral seperti pada :

Madrasah-madrasah itu semuanya adalah hasil usaha partikelir yang, yang mendapat pengawasan dari Departemen Agama. Madrasah-madrasah yang sudah mendapat pengakuan dari Departemen Agama menerima bantuan dari Departemen itu: dengan hitungan tiap-tiap murid pada madrasah-madrasah milik perseorangan menerima Rp. 10,- tiap tahun, sedangakan madrasah milik organisasi menerima untuk tiap-tiap murid Rp. 30,- tiap tahun (Sejak tahun 1966 bantuan berupa uang dari Departemen Agama ditiadakan).

\section{Madrasah Dewasa Ini}

Belakangan ini banyak sekali kritik yang dilontarkan oleh para pakar terhadap sistem dan model pendidikan kita. Di antara kritik tersebut dinyatakan oleh Profesor H. A. R Tilaar bahwa pendidikan tak mampu lagi menanamkan persatuan bangsa. Pola indroktinasi ideologi ternyata tidak berhasil karena terdapatkesenjangan antara nilai-nilai yang diinginkan dengan praktek kehidupan nilai yang diberikan para pemimpin. Contohnya, pemerintah dan pemimpin yang korup tidak bisa mengharapkan rakyat melaksanakan nilai-nilai yang baik. Padahal, kata Tilaar, pendidikan membutuhkan keteladanan.
Diperlukan suatu peninjauan kembali mengenai posisi madrasah di dalam dinamika kehidupan masyarakat dan bangsa Indonesia. Denagn kata lain, madrasah perlu merumuskan kembali posisinya atau reposisi madrasah. Apabial tidak demikian maka madrasah akan kehilangan identitasnya dan menjadisepertisekolahyangdiselenggarakan oleh pemerintah selama ini. Hal demikian apakah masih mempunyai dasar untuk kelanjutan hidup madrasah?

Telah kita lihat tuntutan masyarakat Indonesia baru, antara lain demokratisasi pendidikan yang memupuk lahirnya tingkah laku peserta didik yang demokratis, hubungan yang demokratis antara guru dan peserta didik demi perkembangan berpikir yang kreatif, pendidikan agama yang membentuk nilai-nilai moral serta memperkuat iman dan taqwa, menguasai iptek, serta memupuk kerjasama dalam persaingan sebagaimana yang dituntut oleh masyarakat global.

\section{Kesimpulan}

Pendidikan Islam mempunyai sejarah yang panjang dan berkembang seiring dengan laju peradaban Islam, kedatangan Islam mengantarkan transformasi yang sangat berarti bagi masyarakat arab. Sebelum kedatangan Islam masyarakat arab belum memiliki model pendidikan formal yang sistematis. Mereka hidup dalam suatau tatatanan yang disebut dengan Jahiliyyah. Suatu polemik yang selalu muncul diantara pemerhati sejarah pendidikan Islam adalamengenai madrasah yang pertama kali muncul dalam pendidikan Islam. Pada awal kemerdekaan tidak dengan sendirinya Madrasah di masukkan kedalam system pendidikan Nasional. Madrasah memang terus hidup tetapi tidak memperoleh bantuan sepenuhnya dari pemerintah. Madrasah dan dunia pendidikan Islam pada umumnya dibiarkan hidup meskipun dalam keadaan yang sangat sederhana dan hidup apa adanya. 
Memasuki abad ke-21, bangsa Indonesia di hadapkan pada perubahan global yang menuntut adanya system keterbukaan politik, ekonomi, dan budaya. Perubahan yang terjadi adanya peraturan ini pada gilirannya akan mempengaruhi tata nilai kehidupan. Lembaga pendidikan diharapkan dapat berperan besar dalam mengatur irama tersebut. Kedudukan yang sentral dan direncanakan secara sistematik, lembaga pendidikan diharapkan dapat menjadi perisai bagi perkembangan budaya serta menjadi motor untuk mempercepat perubahan masyarakat.

\section{Daftar Pustaka}

Akhiruddin, KM. "Lembaga Pendidikan Islam di Nusantara." 25 Juni 2015 Vol 1, no. No 01 (14 September 2017): 204.

P.K, Soedewo. Islam dan Ilmu Pengetahuan. Cetakan Pertama. Jl. Kesehatan IX No. 12 Jakarta Pusat 10160: Penerbit Darul Kutubil Islamiyah, t.t.

Mujib, A dan Madkur, A. Islamic-based Life Skill Education on State Vocational High Schools in Metro. Makalah disampaikan di The First International Conference on Law, Economics and Education. (Metro: Universitas Muhammadiyah Metro, 2016), 43-47.

Sulaiman, Umar. Islam Kosmopolitan: Ikhtiar Pembumian Nilai-Nilai TransendenHumanis di Ruang Publik. Yogyakarta: Freshbooks, 2012.

Sulastri, Tuti. "Fungsi Madrasah dalam Pengembangan Ilmu Pengetahuan Islam." 11 Desember 2016 Vol. 3 No. 2, no. Jurnal Qathrunâ (14 September 2017): 127.

Syamsul Arifin, et, al. Spiritualitas Islam dan Peradaban Masa Depan. Yogyakarta: SIPPRESS, 1996.
Yunus, Mahmud. Sejarah Pendidikan Islam di ndonesia. jakarta: hidakarya agung, t.t. 